\title{
Correction to: Public goods and procreation
}

\author{
Jonathan Anomaly ${ }^{1}$
}

Published online: 6 May 2019

(c) The Author(s) 2019

\section{Correction to: Monash Bioeth. Rev. (2014) 32:172-188 https://doi.org/10.1007/s40592-014-0011-x}

The article Public goods and procreation, written by Jonathan Anomaly, was originally published electronically on the publisher's internet portal (currently SpringerLink) on 10 December 2014 without open access.

With the author's decision to opt for Open Choice the copyright of the article changed on 10 April 2019 and the article is forthwith distributed under the terms of the Creative Commons Attribution 4.0 International License (http://creativeco mmons.org/licenses/by/4.0/), which permits use, duplication, adaptation, distribution and reproduction in any medium or format, as long as you give appropriate credit to the original author(s) and the source, provide a link to the Creative Commons license and indicate if changes were made.

Publisher's Note Springer Nature remains neutral with regard to jurisdictional claims in published maps and institutional affiliations.

The original article can be found online at https://doi.org/10.1007/s40592-014-0011-x.

Jonathan Anomaly

jonathan.anomaly@duke.edu

1 Department of Philosophy, Politics, and Economics, Duke University, Durham, USA 